\title{
The Influence of School Type on the Initial Smoking Age among Adolescence: A Survey in Pontianak City, West Kalimantan, Indonesia
}

\author{
Jamaliah $^{1} \&$ Restiatun Massardi ${ }^{1}$ \\ ${ }^{1}$ Department of Economics, Faculty of Economics and Business, Universitas Tanjungpura, West Kalimantan, \\ Indonesia \\ Correspondence: Jamaliah, Department of Economics, Faculty of Economics and Business, Universitas \\ Tanjungpura, West Kalimantan, Indonesia. Tel: 62-0561-766-840.
}

Received: November 9, 2017

Accepted: December 6, 2017 Online Published: December 8, 2017

doi:10.20849/ajsss.v2i4.240

URL: https://doi.org/10.20849/ajsss.v2i4.240

\begin{abstract}
Smoking habit usually started at adolescence. The decision to start smoking is heavily influenced by one's surroundings, both school and family. Adolescents in general are in their school phase, so that most of their times are spent at school. Hence, school environment greatly influences one's personality, including one's decision to smoke. It has been decided that school is a non-smoking zone. Each school, either public or private, has put some surveillances on their students, particularly in terms of smoking. Each school conducts its own surveillance method. This difference shall shape different peer circumstance for each adolescent. This research aims to discover whether certain school type (from primary to high school) influences adolescent's initial smoking age, without ignoring the smoking habit in one's family (parental-habit transformation). This research employs a survey method. The survey is conducted randomly to 500 respondents from 18 years old to 23 years old. It is also found out that family's smoking habit and mother's educational background significantly influence the adolescent's initial smoking age.
\end{abstract}

Keywords: initial smoking age, school type, adolescent

\section{Introduction}

There is a fact that most adults who are smoking regularly started their smoking habit since they were adolescents (Giovino, 2002). The earlier one started to smoke, the harder for him/her to stop the habit.In other words, the possibility for one to stop smoking is inversely related to initial smoking age (Coambs, Seline, and Kozlowski, 1992; Breslau and Peterson, 1996). If one does not start to smoke as an adolescent, it is highly unlikely for him/her to smoke (US Department of Health and Human services, 1994).

In the UK, almost 28 percent of male and 24 percent of female are smoking. Most smokers started when they were adolescents and this habit remains after they are adults. It was also found out that one-third 11 years old kids in the UK had started smoking; while two-third started at 16 years old (ASH, 2005). Similar results were also found out at the statististical data of British National Survey in 1997 where 19 percent participants (11-16 years old) were smokers. At the survey, it was discovered that most of them admitted it is hard to quit smoking. It increased the assumption that they would keep smoking in a long term.

\subsection{Steps to Be Daily Smoker}

There are several steps for a youth to be a daily smoker. In the beginning, youth just try to smoke, but since it goes hand in hand with habit development of smoking, youth can be one of daily smoker. When youth try smoking for the first time, usually they will experience behavior and intensity development of smoking and the imagination of how smoking is (Flay Br, 1994). In this stage, education of smoking risks is the most appropriate way to end smoking habit which just started. School is an institution which has authorities to do this.

The decision to smoke is made by most adolescents when they are at school where they spend most of their time at. Even though almost all schools - public or privat-have regulated schools as a non-smoking zone, but there are always new adolescents or students becoming smokers. Based on the Center for Disease Control and Prevention (2014), each day, every 3200 adolescents (less than 18 years old) smokes their first cigarettes; while 2100 adolescents who are initially non-regular smokers become regular ones.

It can be said that the surveillance system on smoking habit at school is one of the most important determinants 
in influencing an adolescent's decision to start smoking. If the surveillance system is good, it will decrease the prevalence of smoking adolescents at school. A strong support from school for no-smoking regulation protects adolescents and hinders them from the willingness to smoke. School as formal education institution is responsible to produce educated human resource, who will be more efficient producers towards a good health (see Grossman, 1972). School and society educate individuals until they are matured.

\subsection{Quality Differences between Private Schools and Public Schools}

There are different perspectives on the quality of public and private schools. Based on the previous studies (Angrist et al. 2002; Cox and Jimenez, 1991; Evans and Schwab, 1995; Neal, 1997), they discovered that private schools have better academic achievements than public ones. Meanwhile, different findings were found by Strauss et al. (2004) and Serrato and Melnick (1995). It was discovered that public schools have better quality than private ones based on their input schooling and low cost for each student. However, if it is based on teacher-student ratio, the private schools' qualities are better than the public ones, because their ratios are 44 percent lower than those of public schools.

Lower cost per student in public schools creates a tendency that low-income households will send their kids to public schools. Low-income households possibly give a little amount of pocket money to their kids; thus, it is unlikely for the kids to buy cigarettes. On the other hand, lower student-teacher ratio in the private school makes it possible to put better surveillance on students' behaviors; hence, the prevalence for students to smoke becomes smaller.

The research on the relationship between pocket money, academic achievement, and smoking habit was conducted by Abdalla et al. (2009). The findings stated that 657 (43.7\%) out of 1505 students aged 12-19 years old in Tabuk, Saudi Arabia, have ever smoked. The research also found out that adolescence smoking behavior is related to their bad academic achievement and huge amount of pocket money (more than 2 riyals per day).

Those students show that they come from high-income households. Using their income, those households can send their kids to more expensive and more tightly-secured private schools; hence, if an adolescent are sent to private school, his/her prevalence to smoke becomes smaller. On the other hand, seeing bad academic reputation of a smoking adolescent, it may show that they are not the input of a public school; because it is characterized by higher input schooling than private schools. Based on the description above, it is interesting to comprehend how school types (primary, junior, and senior) influence the initial smoking age for adolescence.

\section{Literature Review}

It is important to understand the determinants of the danger from initial smoking in order to develop an effective program and policy to reduce the number of smokers. A more promising solution to this bad habit is by targeting the youth and controlling their smoking behaviors. School is one of the most important institutions capable of playing a role in no-smoking campaign, because a daily smoker usually starts his/her smoking habit at their adolescence, particularly during middle school and high school.

In Indonesia, both of public and private schools enforce various policies regarding smoking behavior. Organizational structure in several schools even directly influences the surveillance and control on the students. Lavato et al. (2010) stated that there are three school characteristics with low smoking-adolescent rate, namely expensive cigarettes price, preventive education on smoking, and zero-tolerance policy for smoking students.

Supervising on cigarette distribution in school is one of instruments to control smoking habits among youth. If cigarette is hardly found in school, youth's prevalence to smoke in school will decrease. In Indonesia, high prevalence of cigarette distribution and risks taken by passive smokers are main challenges in tackling smoking issues (Kompas, April $1^{\text {st }}, 2001$ ). Another challenge in anti - smoking a campaign among youth is the inelastic demand of cigarettes. De Cicca (2002) found that there was no significant relation (sometimes positive) between price and tax on cigarettes and beginning of smoking habit during school ages.

Just like parents, schools can behave preventively or permissively toward smoking behavior. Just like parents, schools' strict supports for anti-smoking regulations play role as protection factors for youth and can prevent them from desire to try smoking (see Mahabee-Gittens et.al., 2012). School staffs and teachers are authorized to enforce no-smoking rules both for students and teachers, as well as to provide educational materials to stop smoking behavior. Several researchers found that schools with no-smoking area have less smoking prevalence and less cigarettes consumption than schools without such rules (Lavato. et al., 2010: 4).

Adolescents' smoking habits can cause various health complications happened at the last stage of adolescence (or even during it), such as reducing lung growth, growing risk for respiratory diseases, and increasing fatty acids in blood. There are evidences that 4 out of 5 people started smoking before they turn adult and those who 
started smoking at young age find it difficult to stop their dependence on nicotine (Departmen of Health and Human Services, 1994). Smoking is always associated to several health problems such as lung diseases, cancer, cardiovascular and metabolism diseases, addiction, and prenatal conditions (Razaz-Rahmati et.al., 2011; Woodgate and Kreklewet, 2012), and even can cause death (Veeranki et.al, 2013). Therefore, a preventive action for adolescence is necessitated to reduce possible diseases and cost caused by smoking (Giovino, 2002; Kuper, Adami, and Boffeta, 2002).

Gruber (2001) found that price has negative and significant influence on smoking habit, but it affects the "older" youngsters more. The influence of price only lies on the number of cigarettes consumed, not on the initial smoking age for adolescents. Based on such results, we can see the effectiveness of tax policy and smoking warning for adolescence; however other determinants influencing adolescents to smoke should have been a priority for researchers and help policy makers designing a comprehensive non-smoking policy.

Bourdobat and Malhotra (2008), using 22,936 samples from Canadian Tobacco Use Monitoring Survey 2002, discovered that 15 years old adolescent is exposed to the highest risk to be a smoker. The danger to start smoking starts is 10 years old, reaches the highest point is 15 years old, and declines after 15 years old. The danger to start smoking at 10 years old happens to male and female adolescents; however male adolescents are more exposed to risk than the female ones. Additionally, the highest risk at 15 years old also applies to both genders. In Indonesia, 10-15 years old adolescents are usually primary and junior high school students. At such age, the school has a role to form their habits.

\section{Research Methodology}

This research uses primary data obtained from survey questionnaire. The 500 respondents are obtained randomly. The respondents' qualifications are 18-23 years old, and high school graduates. Such qualifications are decided because such age range is still considered adolescence; while high school graduates are chosen to find out the influence of a respondent's school type (from primary to high school).

Table 1. Explanatory variables used in the estimate.

\begin{tabular}{|c|c|c|}
\hline Variable & Definition & Values \\
\hline Smok & Initial smoking age & years \\
\hline $\mathrm{PH}$ & $\begin{array}{l}\text { A Dummy; illustrate the status of the primary } \\
\text { school }\end{array}$ & 1 for public school; 0 for private school \\
\hline $\mathrm{JH}$ & $\begin{array}{l}\text { A Dummy; illustrate the status of the junior } \\
\text { high }\end{array}$ & 1 for public school; 0 for private school \\
\hline SH & $\begin{array}{l}\text { A Dummy; illustrate the status of the high } \\
\text { school }\end{array}$ & 1 for public school; 0 for private school \\
\hline Fam & $\begin{array}{l}\text { A Dummy; illustrate the smoking status of the } \\
\text { parents/other family members }\end{array}$ & $\begin{array}{l}1 \text { if any family member smokes; } 0 \text { if there's no } \\
\text { family member smokes }\end{array}$ \\
\hline EdFa & $\begin{array}{c}\text { A Dummy; illustrate father's educational } \\
\text { status }\end{array}$ & $\begin{array}{c}1 \text { if graduated from primary school; } 2 \text { if } \\
\text { graduated from junior high; } 3 \text { if graduated from } \\
\text { high school; } 4 \text { if graduated from higher } \\
\text { education }\end{array}$ \\
\hline EdMo & $\begin{array}{l}\text { A Dummy;illustrate mother's educational } \\
\text { status }\end{array}$ & $\begin{array}{c}1 \text { if graduated from primary school; } 2 \text { if } \\
\text { graduated from junior high; } 3 \text { if graduated from } \\
\text { high school; } 4 \text { if graduated from higher } \\
\text { education }\end{array}$ \\
\hline
\end{tabular}

All data from the variable above shall be analyzed by Ordinary Least Square (OLS). The following is the mathematic equation:

$$
\text { Smok }_{\mathrm{i}}=\alpha_{0}+\alpha_{1} \mathrm{PH}_{\mathrm{i}}+\alpha_{2} \mathrm{JH}_{\mathrm{i}}+\alpha_{3} \mathrm{SH}_{\mathrm{i}}+\alpha_{4} \mathrm{Fam}_{\mathrm{i}}+\alpha_{5} \mathrm{EdFa}_{\mathrm{i}}+\alpha_{7} \mathrm{EdMo}_{\mathrm{i}}+\varepsilon_{\mathrm{i}}
$$

\section{Results and Discussion}

\subsection{Descriptive Analysis}

This survey is conducted to 500 smoking adolescents, ranging from 19 to 24 years old. There are 445 male participants $(89 \%)$ and 55 female participants $(11 \%)$. Much fewer female respondents reflect the number of female smokers which are smaller than female one. It is because most Indonesian considers female smokers as peculiar. Based on age range, the average participant age is 21.25 years old; the youngest one is 18 years old and the oldest one is 23 years old. The average cigarettes smoke per day are 13. 
Based the recipient's sex, the average female's initial smoking age is 17.65 years old; while male's initial age is 16.9 years old. Thus, male smokers generally started their smoking habit younger than the female ones. The average initial smoking age is 16.91 years old.

Based on the type of primary school, there are 448 respondents (89.6\%) graduated from public school; while 52 respondents (10.4\%) graduated from private school. Moreover, based on the type of junior high school, there are 355 respondents (67\%) graduated from public school; while 145 respondents $(33 \%)$ graduated from private school. Lastly, based on the type of senior high or vocational school, there are 350 respondents $(70 \%)$ graduated from public school; while 150 respondents $(30 \%)$ graduated from private school. Table 4.1 illustrates the average initial smoking age of the respondents.

Table 2. Average smoking age of adolescents based on the school type

\begin{tabular}{cccc}
\hline Educational Level & School Type & Number of respondents & $\begin{array}{c}\text { Average initial } \\
\text { smolking age }\end{array}$ \\
\hline Primary School & Public & 52 & 16.93 \\
\cline { 2 - 4 } & Private & 448 & 16.88 \\
\hline Junior High School & Public & 355 & 16.87 \\
\cline { 2 - 4 } & Private & 145 & 17.01 \\
\hline Senior High School & Public & 350 & 16.90 \\
\cline { 2 - 4 } & Private & 150 & 16.93 \\
\hline
\end{tabular}

Source: Primary data

Based on the table above, the youngest smoking age (16.87 years old) occurs to the adolescents graduated from public junior high school; while the oldest smoking age occurs to private school graduates at 17.01 years old.

The smoking habit in the family undeniably influences adolescents' risk to smoking and further affects their decision to start smoking. If another family member smokes, the adolescent usually initiates his/her smoking habit at younger age. The average smoking age for adolescents without smoking family members is 17.31 years old; while the average smoking age for adolescents with smoking family member is 16.36 years old. Table 4.2 below illustrates a complete data.

Table 3. Relationship between smoking family members with initial smoking age

\begin{tabular}{cc}
\hline Smoking Family Member & $\begin{array}{c}\text { Average Initial Smoking Age } \\
\text { (years old) }\end{array}$ \\
\hline Yes & 16.36 \\
\hline No & 17.31 \\
\hline
\end{tabular}

Source: Primary data

Parents' educational level influences the level of education given to the kids about the negative influence of cigarettes on one's health. Based on parents' educational level, the average initial smoking age (17.1 years old) for the oldest adolescent occurs to the highest educational level of mother (bachelor degree or more). While the youngest initial smoking age is discovered for the adolescent with father's education below university level (16.63 years old). It is illustrated in Table 4.3.

Table 4. Relationship between parents' education and initial smoking age

\begin{tabular}{ccc}
\hline & Education & Average Initial Smoking Age \\
\hline \multirow{2}{*}{ Father } & $<$ bachelor & 16.63 \\
\cline { 2 - 3 } & $\geq$ bachelor & 16.99 \\
\hline \multirow{2}{*}{ Mother } & $<$ bachelor & 16,88 \\
\cline { 2 - 3 } & $\geq$ bachelor & 17.1 \\
\hline
\end{tabular}

Source: Primary data 
The findings of previous studies mention that the younger the initial smoking age is the harder to quit smoking. In other words, the possibility to quit smoking is inversely related to initial smoking age (Coambs, Seline, and Kozlowski, 1992; Breslau and Peterson, 1996). This research interestingly finds that the willingness to stop smoking occurs to adolescents with younger initial smoking age (16.62 years old); compared to ones not willing to quit smoking (17.01 years old). Table 4.4 illustrates the research data.

Table 5. Relationship between initial smoking age and decision to quit smoking

Source: Primary data

\begin{tabular}{cc}
\hline Willingness to Quit & Average Initial Smoking Age \\
\hline Yes & 16.62 \\
\hline No & 17,01 \\
\hline
\end{tabular}

\subsection{Analysis of Estimated Results}

Based on the estimated result, the variables significantly influence the initial smoking age for adolescents is the existence of smoking family member (Fam) and mother's educational level (EdMo).Smoking family member strongly influences adolescent's willingness to start smoking early. This variable has negative and significant influence; it means that the existence of smoking member causes adolescents' initial smoking age to be younger. It is in line with the findings of several previous studies (Loureiro, Galdeano, and Vuri, 2006; Sabrina et al., 2012). Those researchers find that the adolescents whose parents smoke are more likely to be smokers, particularly if their older sibling also smokes; thus, those kids are exposed to fourfold risk to be smoker. The complete estimation is illustrated in the table 4.5.

Table 6. Estimated results

\begin{tabular}{ccc}
\hline Variable & Coefficient & t-statistic \\
\hline Constant & 17.08328 & 33.71464 \\
\hline Primary School & 0.121539 & 0.362017 \\
\hline Junior High School & -0.156116 & -0.651068 \\
\hline Senior High School & 0.035060 & 0.148813 \\
\hline Fam & -0.522341 & $-2.4460988^{*}$ \\
\hline EdFa & -0.178339 & -1.379704 \\
\hline EdMo & 0.280579 & $2.274164^{*}$ \\
\hline R-Square 0.632470 & & \\
F-statistic 1.955594 & \\
Prob(F-statistic) 0.070424 & \\
\hline
\end{tabular}

*denote significantly at level $\alpha=5 \%$

Source: Primary data

Based on the table 4.5, mother's educational level (EdMo) has positive and significant influence. It means that the higher mother's educational level is, the higher the initial smoking age is. It also illustrates mother's role to shape her kids' personalities, including their decision to smoke.

\section{Conclusion}

Based on the estimated results, only the existence of smoking family member (Fam) and mother's educational level (EdMo) significantly influence the adolescents' initial smoking age. The first variable negatively and significantly influences the initial smoking age; while the second one significantly and positively influences the initial smoking age.

School types, from primary school to high school, do not significantly influence the initial smoking age among adolescence. The findings show that an adolescent's decision to start smoking is more influenced by his/her family background, not his/her school. This is most possibly caused by the supervising system in schools, both in public and privat, to the smoking habits which can be considered good. 
Existence of family member who smoke cigarettes cause high tolerance level to the risks of smoking, which eventually lead to youth's decision in starting to smoke. This habit will continue to school environment. In schools which strictly implement nonsmoking areas policy, youths might be prevented in smoking. But, do not smoking in schools does not mean they could not smoke elsewhere. So, a family which is equipped by mother's understanding of the smoking's risks will be the main environment which can prevent smoking habits in youths.

\section{References}

Abdalla A.M., A.A. Saeed, B.M. Abdulrahman, A.F. Al-Kaabba1, \& H. Raat. (2009). Correlates of ever-smoking habitamong adolescents in Tabuk,Saudi Arabia. Eastern Mediterranean Health Journal, 15(4), 983-992.

American Psychological Association. (1972). Ethical standards of psychologists. Washington, DC: American Psychological Association.

American Survey of Health (ASH). (2005, January). Basic Facts: One. Retrieved from www.ash.org.uk

Angrist, Joshua, Eric Bettinger, Erik Bloom, Elizabeth King, \& Michael Kremer. (2002). Vouchers for Private Schooling in Colombia: Evidence from a Randomized NaturalExperiment. American Economic Review 92(5), 1535-58. https://doi.org/10.1257/000282802762024629

Anonim. (2001). Kompas, April $1^{\text {st }}$, edition.

Boudarbat, B., \& Malhotra, N. (2008). The Hazard of Starting the Cigarette Smoking Habit. Selected Works from the selected Works of Nisha Malhotra, P.1-24.

Breslau N., \& Peterson E.L. (1996). Smoking cessation in young adults: age at initiation of cigarette smoking and other suspected influences. American $J$ Public Health, 86, 214-20. https://doi.org/10.2105/AJPH.86.2.214

Coambs R.S., Seline L., \& Kozlowski L.T. (1992). Age interacts with heaviness of smoking in predicting success in cessation of smoking. American Journal Epidemiol, 135, 240-6. https://doi.org/10.1093/oxfordjournals.aje.a116277

Cox, Donald, \& Emmanuel Jimenez. (1991). The Relative Effectiveness of Private and Public Schools: Evidence from Two Developing Countries. Journal of Development Economics 34(1-2), 99-121.

DeCicca, P., Kenkel, D., \& Matios, A. (2002). Putting Out The Fire: Will Higher Taxes Reduce The Onset of Youth Smoking. Journal of Political Economy, 110, 144-169. https://doi.org/10.1086/324386

Evans, William, \& Robert Schwab. (1995). Finishing High School and Starting College:Do Catholic Schools Make a Difference? Quarterly Journal of Economics 110(4), 947-74. https://doi.org/10.2307/2946645

Flay B.R. (1985). Psychosocial approaches to smoking prevention: a review of findings. Health Psychology, 4, 449-88. https://doi.org/10.1037/0278-6133.4.5.449

Giovino, G. (2002). Epidemiology of Tobacco Use in The United State. Oncogene, 21, 7326-7340. https://doi.org/10.1038/sj.onc.1205808

Grossman, M. (1972). On The Concept of Health Capital and Demand for Health. Journal of Political Economic, 80, 223-255. https://doi.org/10.1086/259880

Gruber, J. (2001). Youth Smoking in 1990: Why did it Rise and what are The Long Run Implication? American economic Review: Papers and Proceeding, 91(2), 85-90.

Kuper, H., H.O., A., \& P., B. (2002). Tobacco Use, Cancer Causation, and Public Health Impact. Journal Int Med, 251, 455-466. https://doi.org/10.1046/j.1365-2796.2002.00993.x

Loureiro, Maria L., Anna Sanz-de-Galdeano, \& Daniela Vuri. (2006). Smoking Habits: Like Father, Like Son, Like Mother, Like Daughter. IZA Discussion Paper No. 2279.

Mahabee-Gittens, E.M., Xiao, Y., Gordon, J.S., \& Khoury, J.C. (2012). Continued importance of family factors in youth smoking behavior. Nicotine \& Tobacco Research, 14(12), 1458-1466. https://doi.org/10.1093/ntr/nts078

Neal, Derek. (1997). The Effects of Catholic Secondary Schooling on Educational Achievement. Journal of Labor Economics, 15(1), 98- 123. https://doi.org/10.1086/209848

Razaz-Rahmati, N., Nourian, S.R., \& Okoli, C.T. (2011). Does household structure affect adolescent smoking? Public Health Nursing, 29(3), P.191-197. https://doi.org/10.1111/j.1525-1446.2011.00979.x

Serrato, Carl, \& Glen Melnick. (1995). The Indonesian Family Life Survey: Overview and Descriptive Analyses 
of Population, Health and Education data. Publication No.DRU-1 191 -AID, RAND, Santa Monica, Calif.

US Department of Health and Human Services. (1994). Preventing tobacco use among young people. A report of the Surgeon General, 1994. Atlanta, Georgia: Public Health Service, Centers for Disease Control and Prevention,Officeon Smoking and Health. (US Government Printing Office Publication No S/N 017-001-00491-0).

Veeranki, S.P., Mamudu, H.M., Anderson, J.L., \& Zheng, S. (2014). Worldwide never smoking youth susceptibility to smoking. Journal of Adolescent Health, 54, 144-150. https://doi.org/10.1016/j.jadohealth.2013.07.036

Woodgate, R.L., \& Kreklewetz, C.M. (2012). Youth's narratives about family members smoking: Parenting the parent- it's not fair! BioMed Central Public Health, 12(1), 965-977. Retrieved from http://www.biomedcentral.com/1471-2458/12/965

\section{Copyrights}

Copyright for this article is retained by the author(s), with first publication rights granted to the journal.

This is an open-access article distributed under the terms and conditions of the Creative Commons Attribution license (http://creativecommons.org/licenses/by/4.0/). 